\title{
The Power of Motherhood: Black and White Activist Women Redefine the "Political"
}

\author{
Eileen Boris $†$
}

\section{INTRODUCTION}

Yes, it is the great mother-heart reaching out to save her children from war, famine and pestilence; from death, degradation and destruction, that induces her to demand 'Votes for Women,' knowing well that fundamentally it is really a campaign for 'Votes for Children.'1

- [Mrs.] Carrie W. Clifford, Honorary President of the Federation of Colored Women's Clubs of Ohio, 1915.

Good women try always to do good housekeeping. Building inspectors, sanitary inspectors and food inspectors owe their positions to politics. Who then is so well informed as to how these inspectors perform their duties as the women who live in inspected districts and in inspected houses, and who buy food from inspected markets? ${ }^{2}$

- Adella Hunt Logan of the Tuskegee Women's Club, 1912.

In the early twentieth century United States, women of African descent constructed a political voice that refused to be bounded by the separation of public from private, of work from home. Just as African-American women lived lives that knew no such false divisions, so those active in national and local women's organizations drew upon their strength as

$\dagger$ Associate Professor, Department of History, Howard University. Research for this paper was made possible by a Howard University Research Grant for the Social Sciences, Humanities, and Education. I would like to thank the participants at the Fourth Annual Conference on Feminism and Legal Theory, Adele Logan Alexander, Sharon Harley, Nelson Lichtenstein, Nancy Hewitt, and the editors of the Yale Journal of Law and Feminism, especially Stephanie Cotsirilos, for their comments.

1. Clifford, Votes for Children, 10 THE CRISIS 185 (1915).

2. Logan, Colored Women as Voters, 4 THE CRISIs 242, 242-43 (1912). For more information on Adella Hunt Logan, see Adele Logan Alexander, Black Women at Tuskegee: Building a Foundation, 1895-1920 (1987) (unpublished paper from "Afro-American Women and the Vote" Conference). 
mothers to argue for a legal equality that recognized their difference as black and female from the dominant white society. They offered an interpretation of political life that emphasized the role of women as saviors of the race, justifying their activity because they were mothers. Indeed, they connected women's rights, unlike men's, to the experience of motherhood.

This language of social housekeeping extended women's realm from the home into the community, city, and nation. ${ }^{3}$ By claiming expertise and responsibility for non-familial social spaces, black suffragists were redefining the political and demanding votes for women on the basis of their work as - rather than their mere being - mothers. ${ }^{4}$ Black suffragists' discourse of female difference provided them with a unifying vocabulary, one that co-existed with, indeed complemented, another set of metaphors based on equal rights and universal claims. ${ }^{5}$

In their own context, white women activists in the early twentieth century employed a similar vocabulary. But while analysis of the speeches, writings, and programs of women reformers reveal African-American and Euro-American women sharing language, metaphor, and position in relation to lower class women of their groups, the power of "motherhood" led to different outcomes for black and white women when it came to status and rights.

This paper asks: what does it mean that black and white activist women both created texts that relied on motherhood as image, experience, and rhetoric to forge a new, more inclusive definition of the "political"? How similar were the social programs that complemented, followed, or explained such linguistic constructs of womanhood as motherhood? What were the political consequences of a discourse that relied on the same central image - the altruistic, protective, and nurturing mother - that was embodied in the dominant male supremacist and racist culture and the judge-made law of the period, but concurrently harnessed to a reform agenda?

This paper focuses on the African-American women's club movement to illuminate both the texts and contexts of motherhood as a political platform. It suggests the potential compatibility of equality with difference.

3. For a discussion of social housekeeping, see D. Hayden, The Grand Domestic RevoluTION (1981); see also Wortman, Domesticizing the Nineteenth-Century City, 3 Prospects: ANN. AM. Cultural STUd. 531 (1977). For the merging of public and private in the lives of women of color, see Glenn, Racial Ethnic Women's Labor: The Intersection of Race, Gender and Class Oppression, 17 Rev. Radical Pol. Econ. 86 (1985).

4. For an analysis of the women's movement building out of the "dailiness" of life, see B.

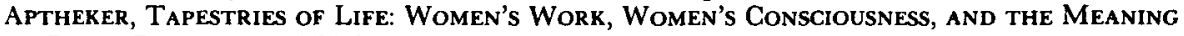
OF DAILY EXPERIENCE (1989).

5. For a fine discussion of the competing claims of difference and equality within both the women's movement and the feminism of the teens, see N. CotT, THE Grounding of ModerN FEmINism 3-50 (1987). To emphasize difference or the mother metaphor, as $I$ do in the above paragraphs, should not be understood to mean that African-American women neglected justice arguments, as we shall see. See, e.g., Logan, Woman Suffrage, 9 Colored AM. MAG. 487 (1905). 
After analyzing aspects of the black women's club movement, it briefly discusses the use of motherhood by white women reformers who also sought to better the homes of working class women, though white women shared less with their "clients," a social group distinguishable from themselves by class and ethnicity, than did black club women with the masses of African-Americans. Finally, this paper considers how the feminist discourse on motherhood, even as it redefined the subjects and objects of politics in the late nineteenth and early twentieth centuries, never escaped legal definitions of motherhood, as seen in labor legislation which sought to protect mothers, but excluded the paid labor of African-American women. Within the word "mother," as used by many reformers and makers of public policy, lurked the referent "white," the very association fought against by activist black women. Nevertheless, black women challenged Jim Crow laws and public policy in ways that demanded equality on the basis of recognized difference. Equal justice under the law, after all, need not obliterate difference. ${ }^{6}$ We can be equal without being identical.

\section{The Historical and Political Underpinnings of "Motherhood" in the Early TWentieth Century Women's MOVEMENT}

To explore the political differences underlying the term "motherhood" for black and white women activists, we must understand "language . . . in terms of competing discourses, competing ways of giving meaning to the the world, which imply differences in the organization of social power, [so that] language becomes an important site of political struggle."7 Only a

6. For one discussion of the problem of formal versus substantive equality, see Wasserstrom, $R a$ cism, Sexism, and Preferential Treatment: An Approach to the the Topics, 24 UCLA L. REV. 581 (1977).

7. C. Weedon, Feminist Practice and Poststructuralist Theory 24 (1987). A feminist poststructuralism reminds us that "[s]ocial meanings are produced within social institutions and practices in which individuals, who are shaped by these institutions, are agents of change, rather than its authors, change which may either serve hegemonic interests or challenge existing power relations." Id. at 25. A signifier, like "mother" or "motherhood," has no fixed signified, because its meaning depends on the discursive context, a specific text, in which it appears and that context is not ahistorical. The context is a product of economic, legal, social, and political struggle.

Language is accented differently by competing groups, and therefore the terrain of language is a terrain of power relations. This struggle within and over language reveals the nature of the structure of social relations and the hierarchy of power, not the nature of one particular group.

The sign, then, is an arena of struggle and a construct between socially organized persons in the process of their interaction; the forms that signs take are conditioned by the social organization of the participants involved and also by the immediate conditions of their interactions. . . . [W]e must be historically specific and aware of the differently oriented social interests within one and the same sign community.

H. Carby, Reconstructing Womanhood, the Emergence of the Afro-American Woman Novelst 17 (1987) (footnote omitted).

Context also belongs to the interpretive act, itself a site of political struggle. To read the texts of African-American women as if they were written by white women is to negate both the authentic voices of black women and the integrity of their experiences. 
historical account that situates the language of activist women in the context of their lives can distinguish the politics of black motherhood. ${ }^{\mathbf{3}}$

To begin that historical and political account, we must remember that although Hunt Logan and Clifford expressed themselves similarily to the white women who dominated major national women's groups, ${ }^{\theta}$ few of the leaders in these and other white women's organizations welcomed Hunt Logan and Clifford as sisters in the women's movement of their day. ${ }^{10}$ For Hunt Logan and Clifford were African-American women, and though privileged by education and wealth compared to the masses of their race, they felt the burden of black womanhood and black motherhood during a time that historians usually refer to as the Progressive Era, but which we must reconceptualize as an era of disenfranchisement of all women and black men, and of legalized segregation. ${ }^{11}$ Consequently, the practices of women like Clifford and Hunt Logan, as well as their rhetoric, must be understood in the context of the actual conditions of black family life.

At the turn of the century, infant mortality and mothers working outside the home were both more common in the black community than in the white. In Washington, D.C., from 1888 to 1892 , the death rate among black children stood at 15 per thousand, nearly three times greater than among whites. ${ }^{12}$ As early as the 1870 census, at least three times as many black, compared to white, Southern urban women listed an occupation, while by the early twentieth century, up to $70 \%$ of black women were earning wages at some point during the year, which meant that five times the number of married black, compared to white, women were in the labor force. ${ }^{13}$ Reporting on Atlanta, Nashville, and Cambridge, Massachu-

For a summary of theoretical discourse from a feminist perspective, see WEEDON at 24-25. See also de Lauretis, Feminist Studies/Critical Studies: Issues, Terms, Contests, in Feminist Studies/CrITICAL Studies 5-19 (de Lauretis, ed. 1986); Alcoff, Cultural Feminism Versus Poststructuralism: The Identity Crisis in Feminist Theory, 13 Signs 405 (1988); Poovey, Feminism and Deconstruction, 14 Feminist STUd. 51 (1988).

8. For an analysis of black motherhood, see Omolade, The Unbroken Circle: A Historical and Contemporary Study of Black Single Mothers and Their Families, 3 Wis. Women's L.J. 239 (1987).

9. Among such organizations were the National American Women's Suffrage Association (NAWSA), the General Federation of Women's Clubs (GFWC), and the National Consumers' League (NCL).

10. For the history of African-Americans and suffrage, see Terborg-Penn, Disenchanted Black Feminists: Prelude and Postscript to the Passage of the Nineteenth Amendment, in Decades of Discontent: The Women's Movement: 1920-1940 261 (1983); Terborg-Penn, Afro-Americans in the Struggle for Woman Suffrage, (1977) (unpublished Ph.D. dissertation, Howard University). See also A. Davis, Women, Race \& Class (1981), especially Racism in the Woman Suffrage Movement at 70; Woman Suffrage at the Turn of the Century: the Rising Influence of Racism at 110; and Working Women, Black Women and the History of the Suffrage Movement, at 137.

11. For the best survey of this period, one that links Progressive electorial reforms with Jim Crow segregation, see N. Painter, Standing at ARmageddon: The United States, 1877-1919 (1987).

12. Mortality Among Negroes in Cities, in 1 The American Negro: History and LiteraTURE (The Atlanta University Publications, No. 1) 15-16 (original from 1896, found in vol. published 1968).

13. J. Jones, Labor of Love, labor of Sorrow: Black Women, Work, and the Family 
setts, the United States Department of Labor found that females supported "wholly or in part" nearly $60 \%$ of black families. ${ }^{14}$ Most worked as domestics which led them, according to Lucy Laney at the first Atlanta University Conference in 1896, to "be away from the home all day" so that children received inadequate care from an absent and/or exhausted mother. ${ }^{15}$ Nearly all of the $80 \%$ of Southern blacks who were rural lived the poverty-stricken and hard life of the tenant or sharecropper. ${ }^{16}$ These women engaged in family labor (reproduction, dependent care, housework, and sex/affective labor), joined in the farm labor, and sometimes worked for wages for white farmers and housewives. Fertility for both rural and urban women was declining at the turn of the century, but still, among African-Americans, wives of nonagricultural men had, on average, four to six children, with rural women having about eight, actually less than white Southern women. ${ }^{17}$ Yet the amount of household work under non-mechanized conditions remained staggering. ${ }^{18}$

At the same time, the cultural construction of womanhood took middleclass white women as the norm, even though privileged black women appeared to live by its tenets. A 1908 study by Atlanta University defended the virtue of black women but still gave credence to the stereotype of the "bad," "loose" black woman by arguing that "sexual immorality is probably the greatest single plague spot ...,",19 although the study did go on to argue that, "[the plague spot's] greatest cause is slavery and the present utter disregard of a black woman's virtue and self-respect, both in law court and custom in the South."20 Defined by the dominant white culture as breeder and slut, though subjected to sexual harrassment, rape, and intimidation, black women existed outside the boundaries of an ideal of womanhood that the very absence of black women shaped. ${ }^{21}$ The $A+M$ Women's Mutual Improvement Circle could declare, "[t]he women of our circle recognize (as true women all over the land are doing) that without a better home life, the future of our race is indeed precarious," ${ }^{\text {,22 }}$ ignoring

\footnotetext{
65-66, 105 (1985).

14. Social and Physical Condition of Negroes in Cities, in id. (No. 2) at 6.

15. Mortality Among Negroes in Cities, supra note 12 , at 36.

16. J. Jones, supra note 13 , at $72,73-79$.

17. J. Jones, supra note 13 , at 83-84, 107.

18. See Mortality Among Negroes in Cities, supra note 12; Social and Physical Condition of Negroes in Cities, supra note 14 . General demographic and social conditions are summarized in $\mathbf{J}$. JONES, supra note 13, at 65-66, 71-87, 91-118 (1985).

19. The Negro American Family, in 1 The American Negro, supra note 12, (No. 13) at 41 (original from 1908, found in vol. published 1968).

20. Id.

21. Carby is quite helpful in articulating this point. See H. Carby, supra note 7, at 30 . On the history of violence against black women, see Hall, "The Mind That Burns in Each Body": Women, Rape, and Racial Violence, in Powers of Desire: The Politics of Sexualtry 328-49 (1983); Rape, Racism and the Myth of the Black Rapist in A. DAvis, supra note 10, at 172-201.

22. National Association of Colored Women, unpublished manuscript reports to 1899 Convention, in Mary Church Terrell Papers [hereinafter Terrell Papers] (folder in Carton 23) (available at Library of Congress).
} 
that the dominant culture denied to the $\mathrm{A}+\mathrm{M}$ women inclusion within their own term, "true women." As the educator Anna Julia Cooper declared before the Women's Congress at the World's Columbian Exposition in 1893,

[although] in the eyes of the highest tribunal in America [the black woman was] deemed no more than a chattel, an irresponsible thing, a dull block, to be drawn hither or thither at the volition of an owner, still the Afro-American woman maintained ideals of womanhood unshamed by any ever conceived. ${ }^{23}$

Outspoken women like Cooper defied this denial of the status of mothers, daughters, sisters, that is, woman, to African-Americans. ${ }^{24}$

Because black women stood outside the boundaries of "true womanhood," as defined by the dominant culture, by being black and descended from slaves (even if their actual ancestors were free), black activists' references to "highest womanhood," to "true motherhood," appeared to subvert a social script written for them by the larger culture that sought to deny them the possibility of nurturing, motherhood, and family maintenance. That is, words that seemed to reflect the hegemonic culture, that seemed to suggest a consciousness steeped in a limited domesticity, in fact challenged that dominant culture. ${ }^{25}$

Thus, through organized self-help, African-American women - the most unequal and the most different in a culture where white men were and are the norm - simultaneously sought equal rights and celebrated their femaleness and their blackness. They sought to advance their race, to uplift black womanhood from the slurs of racism and the legacy of slavery, and they redefined the political and motherhood in the process. ${ }^{26}$ They demonstrated that difference need not stand in binary opposition to equality, that, as one feminist has put it, "equality is not the elimination of difference, and difference does not preclude equality."27 They under-

23. Cooper at the World's Fair, quoted in L. Hutchinson, ANNA J. CoOper: A Voice from THE SOUTH 88 (1981).

24. Id.; See also National Association of Colored Women, unpublished manuscript reports to 1899 Convention, supra note 22.

25. White, Protestant, educated women reformers, on the other hand, forged an alternative ethos against industrial capitalism, yet fed into the dominant sex/gender, class, and racial systems. Their social policies, when translated into law and public policy, ultimately reinforced labor market segmentation because, in part, they never escaped their status as the referent to true womanhood; their arguments merged into those of courts and male-dominated legislatures. For greater elaboration of this argument, see Boris, Reconstructing the Family: Women, Progressive Reform, and the Problem of Social Control, in Women and the Progressive Era (forthcoming 1990).

26. Like their white counterparts, black activists' appeal to motherhood also implied a certain, somewhat ambiguous, differentiation of class since black activists distinguished themselves from their less privileged sisters even while asserting their bonds.

27. Scott, Deconstructing Equality-Versus-Difference: Or, The Uses of Poststructuralist Theory for Feminism, 14 FEMINIST STUD. 33, 38 (1988).

The "equality vs. difference" debate which has polarized feminists in recent years dichotomizes our political choices in ways that key segments of the women's movement of 1900 avoided. 
stood their womanhood as a qualification for citizenship, as a characteristic that enabled them to serve the community rather than as a distinction that hampered participation in the larger social life. ${ }^{\mathbf{2 8}}$

Moreover, they showed that equal rights and cultural differences or diversity can co-exist. After all, they were, for the most part, strong race women, asserting their bonds with black men and children while claiming the same rights for which white women struggled. This maintenance of difference as distinction within the search for equal rights before the law and in social practice predominated, although activist black women shared both Victorian values (such as the work ethic and gentility) and the religiosity associated with white America. Still an equilibrium, not an opposition, between equality and difference existed in the midst of persistent sexual and class divisions within the race, along with racial divisions among women. ${ }^{29}$

\section{Black Women Activists}

\section{A. The National Association of Colored Women}

Formed in 1896 from the merger of the National Federation of AfroAmerican Women with the Colored Women's League of Washington, D.C., the National Association of Colored Women (NACW) unified the philanthropic, self-improvement, and racial uplift efforts of "bourgeois" black women until the mid-1930's when Mary McLeod Bethune, a former president, founded the National Council of Negro Women. ${ }^{30}$ By then, the NACW had limited its efforts to two major departments, "Mother, Home, Child" and "Negro Women in Industry," with its focus on the first of these. ${ }^{31}$ Yet from the start, the association had concentrated on the status of black womanhood, the activities of mothers, and the quality of home life.

Concerned with defending black womanhood from charges of immoral-

28. See N. CotT, supra note 5, at 31-32.

29. For the history of such black women activists, see C. Neverdon-Morton, Afro-AMERICAN Women of the South and THE Advancement of THE Race, 1895-1925 (1989); J. Rouse, Lugenia Burns Hope: Black Southern Reformer (1989). Rouse particularly emphasizes the "Victorian" values of many of these women. See id. at 89-90. See also B. Jones, Mary Church Terrell and the National Association of Colored Women, 1896 to 1901, 67 J. NeGro HIST. 20-33 (1982). Jones calls such women "conservative" rather than "feminist" because they geared their programs and rhetoric to motherhood. In doing so, she superimposes a contemporary definition of the term feminist onto the turn of the century movement. For more on this matter, see below.

30. For a summary of the NACW, its founding, and activities, see its publication, NATIONAL Notes, Mary Church Terrell Collection [hereinafter Terrell Collection] (folders 249, 250, \& 251 in Boxes 102 \& 103) (available at Moorland-Spingarn Research Center, Howard University). For secondary accounts, see P. Giddings, Where AND WHEN I ENTER: The IMPACT OF BLACK WOMEN on Race and Sex in America (1984); W. Moses, The Golden age of Black Nationalism, 1850-1925 103-31 (1978); E. Davis, Lifting as They Climb: The National association of Colored Women (1933). See also Black Women and the Club Movement, in A. DAvis, supra note 10 , at $127-36$.

31. See E. Davis, supra note 30 , at 97-103. 
ity, and discriminated against by the white women's club movement which refused to give credentials to black women at GFWC conventions, black women had organized separately but not as separatists. During the first national meeting called by the Boston New Era Club in 1895, Josephine St. Pierre Ruffin declared,

[o]ur woman's movement is [a] woman's movement in that it is led and directed by women for the good of women and men, for the benefit of all humanity ... we ask the active interest of our men, and, too, we are not drawing the color line: we are women, American women, as intensely interested in all that pertains to us as such as all other American women . . . . ${ }^{32}$

Although asserting their sameness with "all other American women," that is, with white women, organized black women would speak for the race:

[F]or the sake of the thousands of self-sacrificing young women teaching and preaching in lonely southern backwoods, for the noble army of mothers who have given birth to these girls, mothers whose intelligence is only limited by their opportunity to get at books, for the sake of the fine cultured women who have carried off the honors in school here and often abroad, for the sake of our own dignity, the dignity of our race, and the future good name of our children, it is "meet, right, and our bounden duty" to stand forth and declare ourselves and principles, to teach an ignorant and suspicious world that our aims and interests are identical with those of all good aspiring women. $^{\text {ss }}$

As "an army of organized women standing for purity and mental worth," black activists would represent womanhood, a womanhood that was "selfsacrificing," "noble," "fine cultured," "good." They would claim a motherhood previously associated with white women but which black women would redefine in universal terms. But they also stood for "colored women," with special interest in applying universal precepts of home life and womanhood to "the peculiar conditions" of a people only a quarter century removed from slavery and ever caught in the noose of racism through actual lynchings, job discrimination, poverty, and lack of educational opportunity. ${ }^{34}$

Mary Church Terrell best articulated this combination of racial uplift and social motherhood, identity with the race and upholding of genteel values, in her speeches and writings as first President of the NACW be-

32. Address of Josephine St. P. Ruffin, President of Conference (1895), reprinted in id., at 19.

33. Id. at 18 (emphasis added).

34. For the condition of the former slaves, see J. Hope Franklin \& A. Moss Jr., From Slavery to Freedom 224-90 (1988); A. Taylor, Travail and Triumph: Black Life and Culture in the South Since the Civil War (1976). 
tween 1896 and 1901. This daughter of the South's first black millionaire, graduate of Oberlin College, speaker of numerous European languages, and first black member of the District of Columbia Board of Education combined a philosophy of activism grounded in the idea of female difference with promotion of racial and sexual equality based on rights discourse. In a 1912 article, she proclaimed the justice of woman suffrage, comparing the rights due women with those owed black men and thus linking the disfranchisement of both to the same sources. ${ }^{35}$ She ended one report on the work of club women with the declaration, "Seeking no favors because of our color, nor patronage because of our needs, we knock at the bar of Justice and ask for an equal chance." 38

A charter member of the NAACP and supporter of desegregation throughout her life, Terrell advocated civil rights as well as self-help. Privileged and sometimes seen by outsiders as "white," she recognized that her class position carried responsibilities to her race, although she distinguished the respectable and educated women, of whom she was one, from those she judged with the larger culture to be ignorant, lazy, and immoral. She was a feminist, a member of the National Women's Party, and a maternalist, a woman who lost three children within days of their births, who had her daughter Phyllis in 1898 in the midst of her NACW presidency, and who would adopt her brother's daughter seven years later. ${ }^{37}$

For Terrell, motherhood was felt experience as well as an ideal. This confession comes in the midst of recounting the tragic series of infant deaths that marked the early years of her marriage:

The maternal instinct was always abnormally developed in me. As far back as I can remember I have always been very fond of children. I cannot recall that I have ever seen a baby, no matter what its class, color, or condition in life, no matter whether it was homely or beautiful according to recognized standards, no matter whether it was clad in rags or wore dainty raiment, that did not seem dear and cunning to me. ${ }^{38}$

For white readers, Terrell indirectly refutes the negative impact that slavery supposedly had on African-American women's maternal feelings.

35. Terrell, The Justice of Woman Suffrage, 4 THE GRISIS 243-45 (1912).

36. Terrell, Club Work of Colored Women, 30 Southern Workman 438 (1901). See also Terrell, The Justice of Woman Suffrage, supra note 35; Terrell, Woman Suffrage and the 15th Amendment, 10 The CRISIS 191 (1915).

37. For Terrell's biography, see P. Giddings, supra note 30, at 20-22, 109-10; D. STERLING, Black Foremothers: Three Lives (1979); Harley, Mary Church Terrell, in Black Leaders of The Nineteenth Century 307-321 (1988); Sterling, Mary Church Terrell, in Notable American Women: The Modern Period 678-80 (1980). For Terrell's own tale, see M. Terrell, A Colored Woman IN A White World (1968). Giddings, supra note 30, at 110 claims that Terrell never devoted much actual time to motherhood even though she longed for it.

38. M. TERRELL, supra note 37 , at 106-07. 
She reminds us of the social circumstances of mothering, of how her ancestors could not always control the conditions of their mothering and how children born even to well-off women, like Terrell, still could fail to receive adequate medical intervention. She ends with the thought that perhaps here was a blessing in disguise. ${ }^{38}$ Because upstanding black men, like her Memphis friend Thomas Moss, were being lynched, ${ }^{40}$ perhaps it was better that children died. The threat of violent death inured Terrell, the bereaved mother, to her "cruel fate."

As if she had not already clearly linked motherhood and the condition of African-Americans, this passage reinforces an earlier one where Terrell re-imagines "that parting scene when Emmeline, my grandmother, who was then only a small child, was sold from her mother never to see her again."11 This sense of poignancy, derived from the conditions of slavery, hangs over Terrell's discussion. Those actual circumstances - in which women bore children as producers of labor power, where motherhood was not necessarily chosen and where the mother-child bond faced the threat of disruption through sale ${ }^{\mathbf{2}}$ - provides the words "maternal instinct" and "motherhood" with an oppositional quality.

Images of mothers, children, and homes dominated Terrell's NACW speeches and writings. She spoke of the NACW in maternalist terms:

So tenderly has this child of the organized womanhood of the race been nurtured, and so wisely ministered unto by all who have watched prayerfully and waited patiently for its development, that it comes before you today a child hale, hearty, and strong, of which its fond mothers have every reason to be proud. ${ }^{43}$

At the first Biennial Convention of the organization in 1897 , she proclaimed in words repeated in her widely distributed pamphlet, "The Progress of Colored Women":

Believing that it is only through the home that a people can become really good and truly great, the NACW shall enter that sacred domain to inculcate right principles of living and correct false views of life ... [ $[\mathrm{M}]$ ore homes, purer homes, better homes is the text upon which our sermons to the masses must be preached. ${ }^{44}$

\footnotetext{
39. M. TERRELL, supra note 37 , at 108 .

40. For a dramatic account of this event, see P. Giddings, supra note 30 , at 17-18.

41. M. TERRELL, supra note 37 , at 5 .

42. For discussions of motherhood under slavery, see D. White, AR'N't I a Woman? Female Slaves in the Plantation South (1985); Jones, "My Mother Was Much of a Woman:" Black Women, Work, and the Family Under Slavery, 8 FEMINIST STUd. 235 (1982).

43. Terell, The Duty of the National Association of Colored Women to the Race, 16 A.M.E. Church Rev. 340 (1900)

44. President's First Address by Mary Church Terrell, National Association of Colored Women (Sept. 15, 1897) in Terrell Papers (folder in Box 28, Speeches and Writings, 1891-1904) (available at Library of Congress).
} 
Like the authors of the Atlanta University investigations of black life, ${ }^{45}$ Terrell recoiled from what she perceived to be the average home "in which the air is foul, the manners bad and the morale worse."46 Such a home, whether in urban alleys or rural plantations, she called "a menace to health, a breeder of vice, and the abode of crime."47 Surrounded by vice, germs, and dinginess, children suffered. As fitting true mothers, Terrell called upon her "sisters of the Association"

to rescue them [children] from evil and shame ... Listen to the cry of the children, my sisters. Upon you they depend for the light of knowledge, and the blessing of good example. As an organization of women, surely nothing can be nearer our hearts than the children, many of whose lives so sad and dark, we might brighten and bless. ${ }^{4}$

Relying on knowledge gleaned from education and on example, Terrell urged rescue work for the race. The clubwomen would lighten the darkness of the masses. The secular became sacred; the impure, transformed by the "lightness" of the reformers' touch. ${ }^{49}$ Terrell's metaphor reflected both the chasm of class within the black community and the effort to lessen that gap.

But unlike their white counterparts, black women activists shared a common heritage with the poor. Like other women with class privilege, they practiced a politics of maternalism, a superiority of knowledge that led them to dictate standards for those judged below them. Yet their fate interlocked with the objects of their uplift: "Not alone upon the inmates of these hovels are the awful consequences of their filth and immorality visited, but upon the heads of those who sit calmly by and make no effort to stem the tide of disease and vice will venegeance as surely fall." ${ }^{\prime 60}$ Racism bound together the "lesser" with the "better," and may have contributed to the creation of those very categories; ${ }^{, 11}$ certainly class privilege intensified such divisions. Not surprisingly, "Lifting As We Climb" became the motto of the NACW, a motto which embodied the ties of gender and race and reflected a wish to bridge the gulf of class - but on terms set by the club women themselves. ${ }^{.2}$

45. See, e.g., Social and Physical Condition of Negroes in Cities, in 2 The American Negro: History and Literature (The Atlanta Univ. Publications, No. 2, original from 1897, found in vol. published 1968); The Negro American Family, supra note 19.

46. President's First Address by Mary Church Terrell, supra note 44.

47. Id.

48. Id.

49. Here it appears that a class ranking all too often based on color reinforced the English language which links darkness with evil.

50. President's First Address by Mary Church Terrell, supra note 44.

51. Id.; For this sense of connection, see, e.g., Terrell, supra, note 43 at 347.

52. For an insightful analysis of this point, see D. White, Gender, Race, and Class and National Black Women's Organizations, (Feb. 24, 1988) (Black History Month Talk, Howard University). See also D. White, Fettered Sisterhood: Class and Classism in Early Twentieth Century Black Women's 
Next to the educated "better" women of the race stood both the masses of mothers in need and the white mothers with power to stymie the efforts of all black mothers. In both cases, Terrell's feminism suggests an incomplete sisterhood, despite appeals to the fairer ladies and expressions of solidarity with the darker masses. Before the 1899 Third National Congress of Mothers, a predominantly white organization devoted to the principles of an "educated" motherhood, ${ }^{\text {ss }}$ she compared the expectations that white and black mothers could have for their children and thus highlighted the difference that racism made for motherhood in consciousness and practice:

Contrast, if you will, the feelings of hope and joy which thrill the heart of the white mother with those which stir the soul of her colored sister. Put yourselves for one minute in her place, (you could not endure the strain longer) and imagine, if you can, how you would feel if similarly situated - As a mother of the ["weaker" crossed out, and "oppressed" scratched in above] race clasps to her bosom the babe which she loves as fondly as you do yours, her heart cannot thrill with joyful anticipations of the future. For before her child she sees the thorny path of prejudice and proscription which his little feet must tread - She knows that no matter how great his ability, or how lofty his ambition, there are comparatively few avocations in which any one of his race may hope to succeed ... So rough does the way of her infant appear to many a poor black mother that instead of thrilling with the joy which you feel, as you clasp your little one to your breast, she trembles with apprehension and despair. ${ }^{54}$

As a representative of black womanhood, she appealed, "[i]n the name of the children of my race, Mothers of the National Congress, I come, asking you to do all in your power by word and deed to give them the opportunities which you desire for your own." ${ }^{\circ 5}$ By virtue of a shared motherhood, Terrell asked white women to provide equal opportunity for black children by teaching their own children "to be just and broad enough to judge men and women by their instrinsic merit, rather than by the adventitious circumstances of race, or color or creed." ${ }^{36}$ Here the experience of motherhood, based on women's difference from men, opens the door to the argument for justice on the basis of universal human qualities.

History (Nov. 5, 1989) (unpublished paper presented to the American Studies Association, Toronto, Canada). In this recent work, White further elaborates on classism and sexism within the AfricanAmerican movement of the period.

53. For the Congress, see S. Rothman, Woman's Proper Place: A History of Changing Ideals and Practices, 1870 to the Present 103-06 (1978).

54. M. Terrell, Greetings from The National Association of Colored Women to the National Congress of Mothers, Third National Congress of Mothers, 1899, in Terrell Papers (folder in Box 26) (available at Library of Congress).

55. Id.

56. Id. 
Yet even as Terrell pleaded to the mothers of the men who have power in the land, even as she suggested to her Association sisters that they follow the lead of the Mothers' Congress, she pointed out that white women were not perfect either. In her 1897 Presidential Address she claimed,

[i]f the women of the dominant race with all the centuries of education, culture and refinement back of them, with all their wealth of opportunity ever present with them, if these women ... felt the necessity of calling a Mother's Congress that they might be enlightened as to the best methods of rearing children and conducting their homes, how much more do the women of our own race from whom the shackles of slavery have just fallen need information on the same subjects? ${ }^{07}$

Nonetheless, even as she revealed the imperfections of white women, she lamented the ignorance of women of her own race (but not her sister club women) and wished to expose them to the knowledge within the grasp of whites.

\section{B. Into the Home}

Black activists took their work directly into the home. While organizations like the white National Mothers' Congress were intellectually organized by the era's thrust towards scientism, black women's own Mothers' Conferences were grounded in the black church. Their membership would somewhat overlap with club movements, like Terrell's, that blossomed around the same time, but Mothers' Conferences probably embraced a wider class of women because of the Conferences' church roots. The Conferences relied on religion to provide the text for education. Respectability became this text's major lesson. ${ }^{88}$

Under the leadership of Sister J.P. Moore of Spelman Seminary of Atlanta, Baptist and African Methodist Episcopal women throughout Arkansas, Tennessee, Alabama, Georgia, and North Carolina established in the early 1890's fireside schools, bible bands, and mother's clubs out of the belief that "we must have good mothers before we can develop a good race of people." Ass Assuming that mothers are responsible for the moral, religious, and social development of their children, the movement under Sister Moore counseled women to train their children for God, teach them values rather than good dress, and make a happy, clean, comfortable but not

57. President's First Address by Mary Church Terrell, supra note 44.

58. Basically secular in their thinking, Terrell and Hunt Logan stood in contrast with the religious tone generally found among the club women.

59. Address by E.C. Morris, President of the Baptist State Convention of Arkansas in 1894 Minutes of the Second Mothers' Conference Held in Pine Bluff, Ark., September 8th, 9th and 10th, 1894, in Terrell Papers (microfilm roll 17, frames 566-88 at 12) (available at Library of Congress); see generally id. at $41,48-49$. There were nearly 500 of these clubs/schools at that time. 
luxurious home. The group's Resolutions on Improving the House in Which We Live, for example, called for having, if possible, more than the common one room house of the rural South, separate bedroom areas for boys and girls, and a dining room aranged so the family could sit down and eat together - goals that would be taken up by the NACW. In the various guidelines of the clubs - including the "Mother's pledge" Victorian values of work and deportment joined with celebrations of the mother-child bond and exhortations to labor for God and the race. For their fireside or home school, mothers were to read to their children Peep of Day, Temperance Reader, and the monthly magazine, Hope, especially the "Monthly Talk to the Young." They also were to report monthly to church and quarterly to the Fireside headquarters, presumably to discuss their progress in setting "a good pattern for my children in their daily life" and in training them for God. ${ }^{\text {Bo }}$

The voices of women on the reconsituted plantations of tenant farmers and wage laborers are absent from the proceedings of the NACW but come through in the minutes of this earlier 1894 Mothers' Conference. One woman confessed:

I have worked hard all day in the field, and walked five miles to hear this missionary from Sister J.P. Moore's school. I have not seen her, but I love her for the help she has given me through paper Hope. All my family loves and reads it daily. It has brought joy and sunshine into my home; it has helped me to give up my frowns and cross words, and be more loving, gentle and sweet. ${ }^{61}$

Another from Wakefield, North Carolina, reported how the mother's pledge made her "give up my snuff," "love my husband better and treat him more kindly," take better care of her children, and be a better housekeeper. "It makes everything go better about the plantation, because we have pledged ourselves to do better."B2 Significantly, "this pledge has greatly improved not only the mothers, but the fathers and the children in our neighborhood."Bs Mothers' clubs represented the work of mothers for the race that extended beyond the confines of the home.

The NACW also placed the establishment of mothers' clubs -along with day nurseries and kindergartens - at the top of its priorities. In such actions we see an acceptance of paid labor for mothers as a necessary reality. We also see both the bonds these privileged black women felt with their less well-off sisters and their sense of distance. Again Terrell expressed this tension. Addressing the NAWC in 1899, she exhorted,

60. Id. at $15,41-42,48$.

61. Id. at 25 .

62. Id. at 37 .

63. Id. 
[t]o our poor benighted ["underprivileged" written above these words in speech draft] sisters in the Black Belt of Alabama we have gone, and have been both a help and a comfort to these women, through the darkness of whose ignorance of everything that makes life sweet . . no ray of light would have penetrated but for us. ${ }^{64}$

Woven within such professions of concern comes a sense of superiority but also a fear: fear that their sameness (race and gender) will obscure their difference (class and education). This class concern partially lay behind the crusade against the one room cabin, for morality and modesty, because "a majority of the dominant race . . . insists upon judging the Negro by his lowest and most vicious representatives instead of by the more intelligent and worthy classes." ple" was judged by the state of the masses, Terrell called upon "the more favored colored women," the bringers of light, to influence "their illiterate and unfortunate sisters," the receivers of advice, in whose hands lay the power to shape the homes, and thus, the morals of the race. But she also desired to improve the daily standard of living of those below her. ${ }^{88}$

Mothers' clubs thus not only improved home life but also turned into a popular vehicle for cross-class association and for social betterment among African-American women. The Ladies Auxiliary of the District of Columbia reported on their mothers' meetings, held weekly in a chapel, with coffee and rolls after short talks: "The mothers are composed of working women, taught to make their own clothing. They are permitted to pay so much per week for the material until paid for and are entitled to the garments they make. They are also instructed how to keep their own houses neat and clean." nois also claimed success: "Mothers have gone out encouraged, homes have been made better and happier; good resolutions have been made and kept by those who had felt almost alone." Meigs Institute in Alabama brought together the mothers and daughters among the plantation women to build up their mutual "confidence." It boasted of success: "[T]heir homes are neat and clean, pictures on their walls, flowers growing in the yards, strings no longer are wrapped around

64. President's Address by Mary Church Terrell, The Duty of the National Association of Colored Women to the Race, Second Biennial Meeting (August 14-16, 1899), in Terrell Papers (Box 28) (available at Library of Congress).

65. Terrell, The Progress of Colored Women (n.d.) at 9, Terrell Collection (folder 149 in Box 102-5)(available at Moorland-Spingarn Research Center, Howard University)

66. Id. For this concern with morality, see G. Lerner, BlaCk Women IN White America 163-71 (1972).

67. National Association of Colored Women, unpublished manuscript reports to 1897 Convention, in Terrell Papers (folder in Carton 23)(available at Library of Congress).

68. Id. 
the hair, and an air of contentment and a love of house seems to surround their little homes."

\section{Relationship to the Labor Question and Education}

Recognizing that the mothers of their race often had to leave their children to work, the clubwomen accepted the working mother as a worthy mother. ${ }^{70}$ They understood how racism and discrimination insured the inadequacy of most black men's wages, making wage-earning a necessity for thousands of black mothers. ${ }^{71}$ Labor issues, then, became an area for club work. As Terrell explained:

[s]o many families are supported entirely by our women, that if this movement to withhold employment from them continues to grow, we shall soon be confronted by a condition of things, serious and disastrous indeed. It is clearly the duty of this, the only organized body of Colored women in the country to study the labor question, not only as it affects the women, but also as it affects the men. ${ }^{22}$

NACW-sponsored mothers' clubs advocated the establishment of training schools to push domestic science and manual training courses. So did Nannie Helen Burroughs, corresponding secretary to the Baptist Women's Convention. ${ }^{78}$ If blacks were well trained, it was believed, whites could not use the excuse that they lacked proper skills or were unable to produce quality workmanship. But this concern with vocational education never meant that the club women saw such schooling in opposition to liberal arts. Rather, they viewed both as necessary, indeed, as interconnected. ${ }^{74}$

Education for motherhood and housekeeping never meant training for domestic service alone, but belonged to an understanding of women's role that merged the public with the private. Indeed, Burroughs justified her program of "Bible, Bath, Broom, Clean Lives, Clean Bodies, Clean Homes," by observing that "[t]he crux of our economic and social crisis or problems is in the Negro home."75 An educated mother could turn from

69. Id.

70. This definition of motherhood, however, varied from the dominant one

71. Pleck, A Mother's Wages: Income Earning Among Married Italian and Black Women, 1896-1911, in A Heritage of Her Own: Toward a New Social History of American WOMEN 367-92 (1979).

72. Terrell, The Duty of the National Association of Colored Women to the Race, supra note 64, at $347-48$.

73. See Brooks-Barnett, Nannie Burroughs and the Education of Black Women, in THE AFroAmerican Woman: Struggles and Images 97-108 (1978); Palmer, Housework and Domestic Labor: Racial and Technological Change, in My Troubles ARE Going to Have Troubles with Me: Everyday Trials and Triumphs of Women Workers 83.85 (1984).

74. In conrast, DuBois and Booker $T$. Washington posed their debate over black education in terms of an opposition between schooling and liberal arts. For the relation of the club women to the Washington-DuBois debate, see P. Giddincs, supra note 30 , at 102-08.

75. See N. Burroughs, The School of the 3 B's (1938), in Nannie Helen Burroughs Papers (folder 
housekeeping for the family to housekeeping for wages, but it was expected that she would clean her own home as professionally as she would another's. Indeed, the respect that black activists gave housewives is evident in their eligibilty for membership in the National Association of Wage Earners, for which Burroughs, Bethune, and other leaders of the NACW were officers in the early 1920 s. $^{76}$

Local clubs practiced a larger social motherhood that provided necessary services to the community. They established kindergartens, old age homes, working girls' lodgings, social purity projects, female protective leagues, orphanages, and settlements. ${ }^{77}$ Such actions were political. As educator Lucy C. Laney noted, "[w]omen are by nature fitted for teaching very young children ... In the kindergarten and primary school is the salvation of the race." "78 Between 1892 and 1898, the Woman's League of Washington, D.C., for example, organized seven kindergartens serving more than a hundred children. It opened a "mending bureau" to provide sewing for the poor and conducted classes in tailoring. Like white women's clubs, it sought to establish a "diet kitchen" to provide pure milk for infants and thus curb the alarming black infant mortality rate in the nation's capitol. ${ }^{79}$ Clubwomen in Providence, Rhode Island organized a day nursery for mothers "who must go out to work - to leave their little ones to be cared for, instead of having them roam the streets uncared for." ${ }^{\text {"80 }}$ Other locals, such as the Progress Study Club of Kansas City, combined philanthropy with self-improvement, setting up free kindergartens and devoting one afternoon a month to their own efforts at art needlework and lace making. ${ }^{81}$ The Little Rock branch offered instruction in the vocational and liberal arts, including an industrial department with an exchange bureau through which women and girls could offer their

National Trades and Professional School Brochures and Catalogues in Box 309) (available at Library of Congress).

76. See Palmer, supra note 73; Brooks-Barnett, supra note 73; N. Burroughs, supra note 75; Making Their Mark-Results in the Lives of Graduates, National Training School for Women and Girls (1934), at 14, in Burroughs Papers (folder National Trades and Professional School Brochures and Catalogues in Box 309) (available at Library of Congress).

77. E. DAvis, supra note 30, passim; see also National Association of Colored Women, unpublished manuscript reports to 1899 Convention, supra note 22 (comprising reports from numerous local chapters of the Association); for the work of club women, especially in Washington, D. C., see L. Hutchinson, supra note 23, at 85-129; see Efforts for Social Betterment among Negro Americans, in 1 The AMERICAN Negro, supra note 12, (No. 14) 47-64, 119-27 (original from 1908, found in vol. published 1968); for Southern work and the shift from philanthropy to social welfare, see Berkeley, "Colored Ladies Also Contributed": Black Women's Activities from Benevolence to Social Welfare, 1866-1896, in The Web of Southern Social Relations: Women, Family \& EDUCATION (1985).

78. C. NeVERdon-MorTon, supra note 29 , at 5.

79. Some Efforts of American Negroes for their Own Social Betterment, (The Atlanta University Publications, No. 3) at 57-58 (original from 1898, found in vol. published 1969).

80. Efforts for Social Betterment among Negro Americans, supra note 77, at 60; see also id. at 47-64, 119-27.

81. National Association of Colored Women, unpublished manuscript reports to 1899 Convention, supra note 22 . 
handicraft for sale, a training department to improve the skills of domestic workers, and literary meetings for children to direct their reading out of the belief "that if we succeed in forming a taste for pure literature in the home, ... we will have protected its sanctity from violation."82

Applying their education to the home, especially to lower mortality rates, the women of $A+M$ College, Normal, Alabama formed the Women's Mutual Improvement Circle. Like the Tuskegee Women's Club, these college women (teachers, students, and faculty wives) attempted to induce women from the community to hear talks on sanitation, general health, the mother-child relationship, child development, and related matters. Cooking and sewing classes, along with friendly visiting, brought the ideal of educated motherhood to the black belt for the purpose of individual but also race improvement. 83 "A Mothers' Reception" of the Colorado state federation summarized the major themes of all the NACW affiliates, ranging from "Ventilation and Sanitation" to "The Mother's Influence in the Home." It advocated patience instead of whipping and called for "pure mothers for pure children."

\section{Relationship to the Fight Against Segregation and Racial Violence}

Finally, the club work of black women needs to be considered in the context of the violence and social degradation suffered by all AfricanAmericans. From the start, the programs of the NACW addressed Jim Crow laws, the convict labor system, chain gangs - which imprisoned children - and disenfranchisement.

Even before the organization of the movement, club founder and militant journalist Ida Wells Barnett attacked the segregrated trains, which, affronting the dignity of black women, required them to leave the Ladies' Coach for the (men's) smoking car or third class passenger car (for "promiscuous" male and female lower sorts). After being forcibly removed from her usual seat in 1884, Wells Barnett sued the Chesapeake and Ohio Railroad, challenging the Supreme Court's "nullification" of the 1866 Civil Rights bill. ${ }^{\mathbf{8 s}}$ Club women continued to protest what they labelled as improper public accommodations, such as unisex train waiting rooms and bathrooms for "colored." The issue of lynching, as reported by Wells Barnett, stimulated some of the early gatherings of black women. By the 1920 's, the NACW was lobbying for an anti-lynching bill and child labor amendment. Here were the topics of politics, as usually defined, which

82. National Association of Colored Women, unpublished manuscript reports to 1897 Convention, supra note 67; and 1899 Convention, supra note 22. For an exhaustive listing of club activities, especially as associated with Southern Black colleges, see C. NevERDON-MorTon, supra note 29.

83. National Association of Colored Women, unpublished manuscript reports to 1899 Convention, supra note 22.

84. Efforts for Social Betterment among Negro Americans, supra note 77, at 62-63.

85. For this incident, see P. Giddings, supra note 30, at 22-23. See also I. Wells, Crusader for Justice: The Autobiography of IDA B. Wells 18-20 (1970). 
black women as the social mothers of the race claimed as their own. As Anna Julia Cooper proclaimed, "[o]nly the BLACK WOMAN can say 'when and where I enter, in the quiet, undisputed dignity of my womanhood, without violence and without suing or special patronage, then and there the whole Negro race enters with me." "88

\section{III. "SACRed Motherhood": White WOMEn Reformers aNd THE COURTS}

The centrality of motherhood to the arguments and programs of white women reformers at the turn of the century is better known. Since the 1840 's, the women's movement "believed in both sexual equality and a gender-defined society." not see feminism as a rejection of domesticity, but rather as an extension of woman's role and power within the home into the larger society." one young trade unionist put it, "[a] woman is the mother; whether she has children or not her mission is to work for the good of the race."

Certainly the iconography of the National Women's Trade Union League (NWTUL) projected a safe and improved motherhood as the goal of reform. Its 1903 emblem pictured in front of a burst of sunrise, a symbol of hope and victory, a classically-draped mother with child and a warrior woman reaching out to each other in a handclasp, with the League's demands written in the space between them. These demands - "The Eight Hour Day, A Living Wage, To Guard the Home" - reveal how interconnected home and work, family and society were in the minds of women reformers. Only through shorter hours, higher wages, and generally improved working conditions would motherhood be protected and home life secured. This policy contrasted the ethos of capitalism, with its emphasis on commercialism and profits. White women activists offered an

86. Cooper before the colored clergy of the Protestant Episcopal Church, in A. Cooper, A VoICE FROM THE SOUTH 31 (1982).

On the more conventional political activities of black women, see P. GIDDINGs, supra note 30; R. Terborg-Penn, Black Women and Lynching (March 1988) (unpublished paper, Conference on Women in the Progressive Era); A. DAvis, supra note 10, at 110-26; Aptheker, Woman Suffrage and the Crusade Against Lynching, 1890-1920, in WoMan's LEGaCY: EsSays ON RACE, SEX, AND Class in American History 53-76 (1982); Terrell, Club Work of Colored Women, supra note 36, at 438 ; E. DAvis, supra note 30 , at $46-48$.

87. E. Payne, Reform, Labor, and Feminism: Margaret Dreier Robins and the Women's Trade Union League 123 (1988). Of course, white women activists cannot be collapsed into an undifferentiated whole, but their differences became even more prevalent after suffrage. See O'Neill, Everyone was Brave: The Rise and Fall of Feminism in America (1969); Cott, What's in a Name? The Limits of 'Social Feminism,' or, Expanding the Vocabulary of Women's History 76 J. Ам. HisT. 809 (1989). The National Women's Trade Union League, discussed below, was a cross-class women's group, although privileged class "allies" dominated. That makes its use of motherhood all the more significant.

88. Id.

89. Id. at 124. For the links between feminism and motherhood in the work of Margaret Dreier Robins and the National Women's Trade Union League, see id. For the tension between difference and equal rights within feminism, see N. CoTT, supra note 5. 
alternative vision of a nurturing society, a vision projected from the social experience of women - as defined by such women - onto the entire society. The NWTUL adopted an even more powerful image: "\$acred Motherhood," a portrait of a mother running a foot-powered sewing machine in a tenement while nursing her baby. The League made a postcard of this picture which it used to fundraise milk money for the children of strikers and to publicize the plight of women workers during the great Chicago garment strike of 1910-1911.

Such visual texts emphasize how the social welfare measures which historians link to Progressivism were sold through appeals to maternalism on the part of women who represented the mothers of "the race," that is, the human - which, in general dialogue, was often equated with white race. ${ }^{80}$ As Frances Perkins, later Secretary of Labor under Franklin Roosevelt, recalled, success in gaining legislation came from behaving so as to remind politicians "subconsciously of their mothers." also suggest how the larger culture substituted paeans to motherhood and childlife for any adequate resolution of the conflict between capitalist development and the real needs of mothers and children. White reformists often offered the definition of motherhood understood by white, Protestant middle class women to working class ethnic women as a goal toward which to strive.

Yet actual implementation of programs produced a more complex understanding of motherhood, one shaped by recipients and not merely by reformers. To take one example, those fighting tenement homework and sweated labor believed that waged labor had no place in real homes; it degraded motherhood, childhood, and family life. Immigrant women, in contrast, regarded making artificial flowers, sewing garments, and the hundred other activities they performed for wages at home as enabling them to fulfill their duty as mothers and sought to convince judges and investigators to allow them to continue such labor at home. At the same time, immigrant women often used child protection services for their own ends, especially to break down the power of husbands and fathers. Further evidence of "clients" shaping social services comes in the form of letters from rural and urban, poor and middle class women, all of whom influenced the programs of the Children's Bureau. ${ }^{92}$

90. I have analyzed the NWTUL emblem in a different context in E. Boris, ART AND LABOR: Ruskin, Morris and the Craftsman Ideal in America 186-87 (1986); see also E. Payne, supra note 87, at 117-18, 127-28, 134. For analysis of \$acred Motherhood, see Boris, Regulating Industrial Homework: The Triumph of "Sacred Motherhood," 71 J. AM. Hist. 750 (1985).

91. E. PAYNe, supra note 87, at 134.

92. See Boris, Reconstructing the Family, supra note 25; Gordon, Family Violence, Feminism and Social Control, 12 Feminist STud. $453-78$ (1986); Gordon, Child Abuse, Gender, and the Myth of Family Independence: Thoughts on the History of Family Violence and Its Social Control, 1880-1920, 12 N.Y.U. Rev. L. \& Soc. Change 523-37 (1983-84); Ladd-Taylor, Mothers, Child Welfare and the State: Women and the Children's Bureau (March 1988) (unpublished paper from Conference on Women in the Progressive Era). 
Motherhood became contested terrain, the ground upon which reformers battled both capitalists and the immigrant working class. White women's clubs in the late nineteenth century reacted to the pollution of the environment in which their own homes were situated by fighting for pure food and milk and other forms of consumer protection against the shoddy, contaminated products of trusts. They carried forward their project to women from other classes, but from the start they were mothering the world rather than attempting to maintain the home separate from the world. Tenement house reform, pure food and drug laws, public kitchens, playgrounds, maternal and infant welfare, sanitation and water supply, schools, even laws against prostitution and public sexuality, were products of this mother-love that seemed limitless as it expanded from the home to embrace the world. Given that infant mortality was lowest among white middle-class Americans but still high by later twentieth century standards, given the relatively high maternal mortality, given the actual conditions in industrializing cities, "women's efforts to improve the status of mothers and children were not sentimental defenses of traditional patriarchal institutions, but rather were concrete responses to problems that commanded virtually none of American society's attention or resources."

Like black club women, white women activists sought to improve the homes of poorer, less educated women. We can see this most blatantly in the Americanization campaign that reached a feverish pitch with World War I. The YWCA's Edith Terry Bremer argued, "to America the 'Immigration problem' is a great 'problem' of homes." the Federal Bureau of Naturalization argued in Suggestions For Americanization Work Among Foreign-Born Women, "America is no better than its homes" and the mother "determines the kind of home and the health and happiness of the family." "Ts The General Federation of Women's Clubs (GFWG) pledged to "carry the English language and American ways of caring for babies, ventilating the house, preparing American vegetables, instead of the inevitable cabbage, right into the new homes." ${ }^{\text {" In }}$ this light, the work of visiting nurses and social settlement mothers' clubs takes on a multiple identity, expressive of both the alternative ethos of women reformers, their understanding of the material conditions of women's lives, and the solving of urban problems by imposition of

93. See Dye, "\$acred Motherhood": Women and Progressive Reform (1986) (unpublished paper, Organization of American Historians). For a good summary of women's efforts in this area, see also Dye, Reform at the Grassroots: Women, Family and Community in the Progressive Era (March 1988) (unpublished paper from Conference on Women in the Progressive Era); Wortman, Domesticizing the Nineteenth-Century City, supra note 3; M. RITTER BEARD, WOMEN's WORK IN MUNICipaliries (1915). For infant and maternal mortality, see J. LeavitT, Brought to Bed: ChildBEARING IN AMERICA, 1750-1950, at 23-24, 267-68 (1986).

94. J. McClymer, Women As Americanizers, and As Americanized (March 1988) at 12-13 (unpublished paper from Conference on Women in the Progressive Era).

95. Id.

96. Id. at 15 . 
the "American way." In one sense, women reformers were modernizers, rather than merely Americanizers, as they sought to adapt old world practices to the industrial city. ${ }^{97}$

Perhaps the power of motherhood reached its rhetorical heights in the women's peace movement, also of the World War I era. Founders of the Women's Peace Party (WPP) in 1915 (of which Mary Church Terrell was a member), believed that women's qualities as women - their actual or potential motherhood, their ability to talk things out rather than resolve disagreements through violence - generated a desire to preserve life. Women pacifists criticized American foreign policy on the basis of their experience with nurturing and their expectation of what it took to perform that act. Motherhood, then, provided a moral basis for action, a direction for politics. ${ }^{98}$

If the discourse of white women reformers promised a new vision of the industrial city, indeed, a new world, it failed to escape its ties to the dominant culture's conception of womanhood as embodied in the law. As Justice Bradley wrote in his famous concurring opinion in Bradwell $v$. Illinois $^{99}$ during a time when Congressional Reconstruction held sway, but racism kept black women from being included in the idea of "woman":

the civil law, as well as nature herself, has always recognized a wide difference in the respective spheres and destinies of man and woman. Man is, or should be, woman's protector and defender. The natural and proper timidity and delicacy which belongs to the female sex evidently unfits it for many of the occupations of civil life. The constitution of the family organization, which is founded in the divine ordinance, as well as in the nature of things, indicates the domestic sphere as that which properly belongs to the domain and functions of womanhood. ${ }^{100}$

The sexual division of social life became embedded in labor standards legislation in part because Bradwell set up women as a special class to which the equal protection clause failed to apply; the right to contract did not apply because women were treated as a class of dependent persons. The famous Brandeis brief in Muller $v$. Oregon ${ }^{101}$ also reflected pre-existing understandings of women's place and female difference. The arguments of Josephine Goldmark of the National Consumers' League (NCL), who

97. On Americanization, see id. at 12-13, 15.

98. For the most insightful analysis of the WPP, see L. Schott, Against Modernism: The Women's Peace Movement as Cultural Reform (Dec. 1985) (unpublished paper, American Historical Association); Schott, The Woman's Peace Party and the Moral Basis of Women's Pacifism, 8 FronTIERS 22-24 (1985). For an analysis of the slippery consequences of the appeal to female difference among contemporary women peace activists, see M. di Leonardo, Morals, Mothers, and Militarism: Anti-Militarism and Feminist Theory (Book Review) 11 Feminist STUd. 599-617 (1985).

99. 83 U.S. (16 Wall.) 130 (1872).

100. Id. at 141 (Bradley, J., concurring).

101. 208 U.S. $412(1908)$ 
researched much of the brief, reinforced the idea that women were different from men. But her arguments that women were weaker than men sprang from the reality that women working in factories were injuring themselves and, because they were unorganized, had no recourse outside of the law. For Goldmark, using women's alleged "weakness" was a practical tactic in seeking to ensure that the law would improve the lives of these otherwise unprotected, suffering workers.

Significantly, the decision in Muller justified maximum hours for women on the basis of protecting motherhood; women carried with them responsibility for "the well-being of the race."102 Muller represents the sanctification of motherhood which had existed for nearly a century alongside women's attempts to increase their power through their position as mothers. However, the hours laws upheld in Muller, as well as attempts at minimum wage bills and exclusionary legislation like night work laws, applied only to limited groups of women because the legislation exempted from coverage agricultural, non-profit, and usually domestic workers (though not necessarily the black-dominated occupation of laundresses in laundries). That these were the very jobs held by women of color further suggests how the term "mother" in the judge-made discourse referred to white women. ${ }^{103}$ Laws which protected immigrant working women who labored outside the home, then, did not apply to the women on the plantation who were the subjects of efforts by the NACW to uplift the race.

\section{CONCLUSION}

Nearly a century ago, black activist women understood the complex relation between gaining civil rights and maintaining one's heritage, culture, and self-determination. Their referents to justice and difference might not appeal to those who see both "justice" and "difference" constructed by universalistic male dominance. ${ }^{104}$ For African-American women did not discredit motherhood as a female experience shaped by male demands; rather, they based their political programs as well as their epistomology on their own understanding of it. Many traditional African cultures privileged the mother-child bond. ${ }^{105}$ Yet the circumstances of first slavery and

102. Id. at 421-22. For the best exposition of Muller that situates it in a prior history of decisions, see Erickson, Muller v. Oregon Reconsidered: The Origins of A Sex-Based Doctrine of Liberty of Contract, 30 LAB. Hist. 228 (1989). For a fuller discussion of gender and labor standards legislation, see Boris, Quest for Labor Standards in the Era of Eleanor Roosevelt: The Case of Industrial Homework, 2 Wis. Women's L.J. 53 (1986). See also, S. LeHrer, Origins of Protective Labor LEGISLATION FOR WOMEN, 1905-1925 (1987).

103. For an extension of this point, see N. Breen, Shedding Light on Women's Work and Wages: Consequences of Protective Legislation (1988) (unpublished Ph.D. thesis, New School for Social Research).

104. On the problem of providing meaning to such terms, see C. MACKINNON, FEMINISM UNMODIFIED $32-45$ (1987).

105. Rodgers-Rose, Introduction: The Black Woman, A Historical Overview, in ThE Black WOMAN 16-17 (1980). 
then poverty forced many mothers to work away from their children, despite their preferences. Thus, black women, even NACW members, favored mothers' earning wages at home, an activity which white women reformers fought as a social evil. ${ }^{108}$ If they were privileged and recognized their class, they knew how race and racism shaped their lives for better and for worse.

White women reformers did not have to defend their reputations as mothers, as black women activists often did, because the dominant culture found in them the prototype for "woman" and "mother."107 White women could use dominant cultural conceptions as a political tool for exposing the gaps between sentimentality and reality, as embodied in the image of \$acred Motherhood. But, working to improve the actual conditions of mothers and children, as did the black women's clubs, white women still ran up against a difference standard defined by men, including white male judges.

In the case of white activist women, the male dominance of the time shaped both their understandings of difference and equality, which helps to explain the disappointing impact of their efforts. ${ }^{108}$ Women's culture, an alternative set of values based on women's perceptions and experiences as mothers, failed to transform the relations between the sexes or usher in an era of gender justice. Its understanding of motherhood - equated with peace and social nurturance - never overturned the hegemonic culture's equation of motherhood with biology and female dependence on men. Instead, the concept of women as mothers or potential mothers justified limiting women's labor market options without elevating the value of motherhood or nurturing. Social programs would protect working women, but not mothers in the home. Home and workplace remained separate spheres, with the male values of the workplace conflated with the whole of social life. ${ }^{108}$

The work of bourgeois black women also must be evaluated in the context of unequal power relations. To deny the reality of patriarchy, or male power over women, would be to romanticize black male-female relations and to ignore the power of ruling-class white men over all other groups in the society. Yet black women's reliance on motherhood, a status and experience disrupted and denied to their mothers and grandmothers, challenged the subordination of African-Americans. Like their white counterparts, they addressed the actual needs of mothers and children. Even

106. For this matter, see letter from Ida E. Brown, President, New Jersey State Federation of Colored Women's Clubs to Mrs. Simmons, President of the Consumers' League of New Jersey (May 6, 1939) (available at Alexander Library, New Jersey Room, Rutgers University, New Brunswick).

107. For a fine discussion of this point, see Hurtado, Relating to Privilege: Seduction and Rejection in the Subordination of White Women and Women of Color, 14 SIGNS 833, 844-46 (1989).

108. C. MacKinnon, supra note 104 , at 32-33, 40.

109. For more on this point, see Williams, Deconstructing Gender, 87 Mich. L. Rev. 797 (1989) 
though their own classism, along with the racism and sexism of others, sometimes stymied their efforts, the history of black activist women at the turn of the century suggests that justice and difference can co-exist under the banner of self-determination, if not liberation. This history may encourage us to replace an equality standard that fails to incorporate the historic position of African-Americans and of women with a justice standard that incorporates the ethics of care. 
